\title{
Astiotrema turneri n. sp. (Digenea: Plagiorchiidae) from cichlid fishes (Cichlidae: Perciformes) of Lake Malawi, south-eastern Africa
}

\author{
RODNEY A. BRAY ${ }^{1}$, COCK VAN OOSTERHOUT ${ }^{2}$, JONATAN BLAIS ${ }^{3} \&$ JOANNE CABLE $^{4}$ \\ ${ }^{\prime}$ Department of Zoology, Natural History Museum, Cromwell Road, London SW7 5BD, UK \\ ${ }^{2}$ Molecular Ecology and Fisheries Genetics Laboratory, University of Hull, Hull HU6 7RX, UK \\ ${ }^{3}$ Département de Biologie, Québec-Océan, Université Laval, Ste-Foy, Québec, Canada, G1K 7P4 \\ ${ }^{4}$ School of Biosciences, Cardiff University, Cardiff CF10 3TL, UK
}

\begin{abstract}
Astiotrema turneri n. sp. is described from the cichlid species Pseudotropheus zebra, P. emmiltos, Labeotropheus trewavasae and Melanochromis vermivorus from Lake Malawi. It differs from Astiotrema reniferum (as described by Yeh \& Fotedar 1958) in its distinctly broader body, the much smaller cirrus-sac, its oblique testes, the shorter ventral sucker to ovary distance, the vitellarium reaching into the forebody and the extracaecal uterus; from Astiotrema impletum in the sucker-ratio, the longer caeca, the smaller cirrus-sac and the extracaecal uterus; and from Glossidium pedatum (and its probable synonyms Astiotrema lazeri and Afromacroderoides lazerae) in its much broader body shape, in its distinct oesophagus, the intestinal bifurcation in the posterior forebody, in the distinctly oblique testes, the extracaecal uterus and the vitellarium reaching well into the forebody.
\end{abstract}

Key words: Digenea, Plagiorchiidae, Astiotrema turneri n. sp., Cichlidae, Pseudotropheus zebra, Pseudotropheus emmiltos, Labeotropheus trewavasae, Melanochromis vermivorus, Lake Malawi

\section{Introduction}

Theoretical evolutionary studies have long recognized the potential diversifying role of host-parasite coevolution on both host and parasites (e.g. Abrams 2000, Brown \& Vincent 1992, Haldane 1949, Holt 1977), but empirical studies have been slow to match this theoretical interest (Moulia 1999, Nunn et al. 2004, Rundle et al. 2003). Consequently, our understanding of the evolutionary role of interactions between predators/pathogens and prey/hosts in populations and species divergence in the context of adaptive radiation is thin at best (Schluter 2000). Indeed, empirical studies on host-pathogen coevolution are 